\title{
CULTIVATING RESPONSIBILITIES OF VOCATIONAL TEACHERS: A FRAMEWORK FOR PREPARING EDUCATION TO WORK
}

\author{
Didik Nurhadi $^{1}$ and Nyan-Myau Lyau ${ }^{2}$ \\ ${ }^{1}$ State University of Malang, Indonesia; ${ }^{2}$ National Yunlin University of Science and Technology, Taiwan \\ E-mail: didik.nurhadi.ft@um.ac.id
}

\begin{abstract}
Vocational education is responsible for preparing the needs of a global workforce to develop the country's economy. However, issues of vocational education in developing countries are a lack of link and match between education and industry, lack of relevant skills of graduates with the needs of industry owners, the lack of quality, competencies, and professionalism of vocational teachers. The quality of teachers affects the quality of students' skills so that vocational teachers need to understand the role of vocational education to work properly. The question that arises is how to cultivate their responsibilities for preparing vocational education to work? The solution offered is a framework to prepare vocational education to work. This understanding is bringing education to be able to follow the manpower needs in accordance with local and global trends. Furthermore, using a literature review, steps to cultivate teacher's responsibilities were discussed in this paper. Finally, this framework grows teachers' quality in order to support state economic development.
\end{abstract}

Keywords: education foundations, education to work, teacher competency, teacher responsibility, vocational learning

\section{INTRODUCTION}

Vocational education arises due to the reasons for preparing students to be able to work in their professional fields [1]. This education equips graduates with the workability that is standardized by industry owners [2]. This capability is technical skills, professional skills, and adaptable skills in the workplace environment [3]. Equipping students in accordance with the request requires the commitment, communication, and policies from both sides [4]. The success of graduates to work is determined by the perpetrators of educational implementation, both the teachers and students [5]. The teacher's role is vital to transfer knowledge and skills to their students [6]. The quality of teacher competence standards and educational facilities are an essential factor [7]. However, early awareness of the responsibilities of vocational teachers to achieve the demands and challenges of education for employment purposes is indispensable.

Self-awareness of teachers to be responsible is very important because it affects the comfort of teachers in carrying out their duties and it produces a high commitment to all things [8]. They conducted jobs in a professional and dedicated for preparing students to work successfully in the future. However, teachers that are forced to run jobs will produce low commitment and the impact their performance is not optimal. Other impacts, the quality of students' abilities become incompatible with required by the labor market. Finally, the number of unemployed from the vocational education graduates will be increased.

Raising self-awareness of vocational education teachers to their responsibilities is not easy. This process requires some understanding about the meaning of establishment of vocational education in a country. Some experts said that vocational education is established to prepare professionals workers in certain fields required by the state to support state economic development [9]. Developed countries such as America, Germany, and Japan, their economy is growing rapidly due to their vocational education works well. Their high commitment is grown from the self-awareness about the importance of vocational education to work for improving the economy [10]. 
Authors think that the growing responsibility of vocational education teachers can be done through self-awareness about education for work. This awareness is undertaken through a framework for preparing education to work for vocational education teachers. This framework consists of three stages in the responsibilities hierarchy that need to be understood by the teacher of vocational education: the foundations of vocational education, the areas of vocational teacher competence, and the activities of vocational learning.

The purpose of this paper is to foster the responsibility of vocational education teachers in their role to support the state economic development through labor preparation in accordance with required by industry owners in the global market. First aims describe the foundations of vocational education consisting of four components: philosophy, economics, sociology, and psychology. Second, it discusses the competency areas needed by teachers of vocational education. The last purpose explains a strategy to develop learning activities in vocational education.

\section{METHOD}

This research method used a literature review related to cultivating vocational education teachers' responsibilities to prepare graduates to work. More than 40 international journal articles and ten books were reviewed to create a framework and explain how to prepare steps to cultivate teacher's responsibilities, especially in vocational education. Based on literature review, authors discussed it to provide a more in-depth about framework components from the responsibility of vocational education teachers in their role to support the state economic development through labor preparation in accordance with required by industry owners in the global market.

\section{RESULTS AND DISCUSSION}

Understanding of their responsibilities can be established through a framework of understanding to prepare education to work. They will be invited to understand this framework with the three levels that are undertaken in stages through an understanding of the foundation of vocational education, an understanding of the areas of vocational teacher competence and understanding of the activities of vocational learning.

The first level is the understanding of vocational education foundations. Vocational teachers understand these foundations through four components: philosophical, economics, sociology, and psychology.

\section{Philosophical Foundation}

Philosophy is the study of general and fundamental problems concerning such matters as human existence, knowledge, values, reason, mind, language, truth, and the nature of the child, the purpose of education, and much more [11]. The philosophy of education is the most important aspect of technological vocational education and training, and it can be defined as the study of the purposes, processes, nature, and ideals of education [12]. Dewey [13] stated that philosophy is the understanding of education through occupation is a continuous activity with a purpose. Dewey characterizes education as that reconstruction or reorganization of experience which adds to the meaning of experience, and which increases abilities to direct the course of subsequent experience. Education works to reconstruct experience. It does this by manipulating how (experiencing) and what (experienced), but at the same time, this effects the transaction understood holistically, as who, as occupation.

In summary, the philosophical foundation is to give teachers an understanding of how to 
Implement vocational education to carry out the work. Researchers and experts said that vocational education needs to be undertaken through the provision of learning experiences in the industry, the preparation of facilities and learning environment is identic with the real work environment, the teachers' quality who have the competencies are relevant to the labor market, and supported by the vocational education system is effective.

\section{Economical Foundation}

The economic foundation is related to the contributions of vocational education that have made and continues to make to economic stability and advancement of society in a country [14]. Hoeckel [15] stated that one way in which vocational education to contribute toward country economy is through the training of unskilled workers. The economic transformation from an industrial economy to an automated economy brought about a shift in the skill demands of its workers. One area should be examined concerning the economic foundations of vocational education is the apprenticeships [16]. Apprenticeships represent the oldest and most enduring method of vocational training. From these early times until today, history traces the development of apprenticeship as a means of vocational training and state economic advancement.

In summary, the economic foundation gives understanding to the teachers of vocational education to work based on the aim to improve the economy of communities and countries. Therefore they should always print out graduates according to the needs and demand in the global labor market for the present and future.

\section{Sociological Foundation}

Sociology is the study of human social life, groups, and societies [17]. This is human resources of vocational education that having as its subject matter behavior as social beings. The scope of sociology is extremely wide. The needs of a society are many and complex as well. Apart from basic human needs for food, shelter, and love, as well as experience a need to feel productive. Based on the sociological foundation, the vocational education provides for many of these basic human needs in several ways through work behavior, work outcomes, education, social classes, upward mobility, and technical competence. Additional vocational education will improve the individual on an upward slope resulting in increased social status, earning power, and perhaps even living conditions while much emphasis is put on vocational education's ability to improve state economic conditions. It is the related sociological factors that often exert the most profound impact on an individual's life. While as technology advances at a rapidly expanding rate, vocational education is faced with an increased demand for a technically competent workforce. When vocational education prepares individuals to meet these demands not only will give industry satisfaction, but the individual will enjoy high job satisfaction. Providing competence on high levels continuously here becomes the responsibility of the vocational teachers.

In summary, the sociological foundation is the understanding that people work for a living in order to meet the needs and behaviors in the workplace. Education for work needs to construct learners' ability to have skills needed by employers and industry: cognitive, skills, and affective.

\section{Psychological Foundation}

The psychological foundation is based on the individual differences, where every student has its own unique personality, and they have differences in their learning and skills [18]. They are different in nature so they cannot be treated alike in the teaching-learning process, some may be fast learner while other slow. Therefore the teaching and learning in vocational education should be based on the 
above facts, and it should be designed to support the capacity and potentialities of all the students. Psychology plays a vital role in the teaching and learning process. The methods of teaching, the selection of content of subjects and the methods and theories of learning, the overall development of the students and to inculcate the norms of the society in the students. Psychology helps in all the processes above in the development process of the teaching in vocational education.

In summary, the psychological foundation puts the understanding of vocational teachers about the abilities of each learner is different. Teaching and learning activities should be carried out based on the differences they have. The goal is teachers teaching to be fun, exciting, and centered on learners.

At the second level, this framework provides an understanding of the areas of teachers' competency that need to be owned by teachers as their responsibility. Competency areas for vocational teachers include administration, teaching and learning, development and quality assurance, and networking [19].

\section{Administration's Competency Areas}

The vocational education systems should be prepared more efficient and effective with the development of online administrative tools. This will make easy vocational teachers for recording and follow-up of students' progress, time sheets and so on. Then, they will more increase attention to accountability in their working time. Moreover, they also need to manage projects in order to develop their activities, including financial management, tasks of administration, and skills and knowledge required with supported by external funding [20]. The administrative activities and tasks of vocational teachers are numerous. Teachers' workloads are commonly defined as teaching hours, and these administrative activities are additional tasks. Teacher tasks in administrative areas included organization and planning, and project management.

In summary, the responsibility of the administration is to understanding vocational teachers how to manage projects in order to develop their activities, namely financial management, tasks of administration, and skills and knowledge required with supported by external funding. Generally, the administrative activities and tasks of vocational teachers are numerous so that they need understanding about organization and planning, and project management.

\section{Competency Areas of Teaching and Learning}

In the past, teaching and learning in vocational education are about simply telling the learners how things were and showing them how to do things. Currently, several issues have been identified that have influenced the activities them. Those changes are change paradigms in educational theory, diversification of learning environments, fast changes in education structures and priorities and the labor market [21]. The activities of teaching and learning that become vocational teacher responsibility are the planning and preparation, facilitation of teaching and learning, as well as assessment and evaluation. This is carried out to increase teaching and learning optimally undertaken by the teachers.

In summary, the understanding of teaching and learning in vocational education are to tell the learners how things were and showing them how to do things. Several issues that are identified to have influenced their activities are change paradigms in educational theory, diversification of learning environments, fast changes in education structures and priorities and the labor market. While the activities of teaching and learning for vocational teacher responsibility are the planning and preparation, facilitation of teaching and learning, as well as assessment 
and evaluation carried out to increase teaching and learning optimally.

\section{Competency Areas of Development and Quality Assurance}

The quality assurance gives more effects toward all teachers and the process of teaching and learning in vocational education. To invite the teachers to take a part in quality assurance, they need a thorough knowledge of evaluation and assessment and the competencies to apply it in practice. The quality assurance principles and procedures must be respected, and the teachers must possess the ability to implement the necessary changes in the teaching and learning based on the feedback and assessment both from the learners and from external and internal bodies. This is conducted for enhancing approach to the area of professional development. The fields of both development and quality assurance are made to qualify or improve all other professional areas because the continuing professional development of the teacher individual is a decisive factor in the quality enhancement and professionalization of the teaching profession. Responsibilities of development and quality assurance for the vocational teachers include the developing oneself, developing the vocational education, and quality management. These are carried out to develop and to ensure quality assurance of the vocational teachers' professional toward vocational graduates in the labor market both national and international.

In summary, to apply the understanding of teacher responsibility on the development and quality assurance from their job, vocational teachers should possess understanding about the quality assurance principles and procedures must be respected and the ability to implement the necessary changes in the teaching and learning based on the feedback and assessment both from the learners and from external and internal bodies for enhancing approach to the area of professional development.

\section{Competency Areas of Networking}

Vocational teachers should be able to establish, maintain and manage relations with partners and other external stakeholders such as schools/colleges, enterprises, and students' parent. They must keep a close relationship to their professional area in order to keep their selves updated on developments in their field and to be able to include these in the vocational education programs. Internally, they must interact with colleagues and management in order to direct the activities of teaching and learning towards the needs of the global market and the management used. Interaction is further vital for improving the performance and general quality of the teaching and learning [22]. This networking should be shaped by the vocational teachers for their professional consists of internal networking and external networking. This networking is made to know global market development and to ensure quality assurance of the vocational teachers in order to create vocational graduates according to needs of knowledge, skills, and attitudes expected by the global labor market.

In summary about responsibility on networking of vocational teachers, they should be able to establish, maintain and manage relations with partners and other external stakeholders such as schools/colleges, employers, industry, students' parent, etc. They must keep a good relationship with their professional area for updating to develop their competencies and vocational educational programs both internally and externally. This interaction is further vital for improving the performance and general quality of the teaching and learning in vocational education.

Then, the last understanding level is responsibilities about activities of vocational learning. The responsibility of vocational teachers to understand this level consists of four components: clarity, collaboration, confidence, and core system. 


\section{Clarity}

Clarity component is used to describe vocational learning and shape perceptions and expectations of vocational education [23]. Education Council [24] explained that clarity of terminology, purpose, and expectations for vocational learning and vocational education delivered to vocational students requires two things. First, vocational education systems, employers and training centers incorporate the distinction between the vocational learning and vocational education into what they do and how they communicate. Second, vocational education systems, employers, and registered training organization recognize the different purpose of work experience and structured work placements, and the different outcomes expected from them.

In summary, clarity understanding describes vocational learning and shape perceptions and expectations of vocational education. This includes terminology, purpose, and expectations for vocational learning and vocational education.

\section{Collaboration}

The collaboration component will influence an effective of vocational learning and vocational education [25]. Education Council [24] mentioned that collaboration is most effective in supporting vocational learning when vocational education creates opportunities for students' engagement with employers, vocational education systems, training centers, and employers understand the benefits of collaborating and seek opportunities to do so. Consultation is an integral part of national, state and territory policy development processes, consultation on changes to the vocational education system includes vocational education and its systems, vocational education regulators, training package developers, and other stakeholders collaborate to resolve issues at the intersections between policies.
In summary, collaboration understanding is related to effective vocational learning and vocational education. Collaboration is most effective in supporting vocational learning when vocational education creates opportunities for student engagement with employers, vocational education systems, training centers, and employers understand the benefits of collaborating and seek opportunities to do so.

\section{Confidence}

On confidence element, there are two essential elements required for stakeholders to have confidence in vocational learning of vocational education, namely the quality of the programs offered and the information available to help vocational education teachers to understand the purpose and outcomes of these programs [26]. Confidence in vocational learning delivered to vocational students is greater when students and parents have accurate, up-to-date, impartial and studentfriendly information about vocational learning and vocational education based apprenticeships and traineeships. Teachers and career advisers have opportunities to update their knowledge of workplaces and practices. Employers have opportunities to be involved in the design, delivery, and assessment of vocational learning. Mechanisms exist to engage with employers and industry to determine which qualifications of vocational education are appropriate for vocational students and in what circumstances. Schools/colleges, employers and training centers collaborate to ensure streamlined arrangements [24].

In summary, confidence understanding has two essential elements required for stakeholders to have confidence in vocational learning of vocational education: the quality of the programs offered and the information available to help vocational education teachers to understand the purpose and outcomes of these programs. 


\section{Core System}

The core system is the last component. The vocational learning is delivered to vocational students within a complex web of policy settings, governance arrangements, regulatory environments and resourcing decisions [24]. Core systems improve vocational learning in vocational education when existing systems support vocational education through advice on the different ways. Therefore, they can make training available to their students, organize partnership with training package developers, require training packages to provide clear guidance about whether the package is suitable for students, coordinate work experience and structured work placement opportunities, and offer the training courses that students and employers need. Policies provide a supportive environment that minimizes costs and red tape, and facilitates innovation and local flexibility. Short-term, medium-term, and long-term measures of success recognize the many purposes of training delivered to vocational students, and are based on standards similar to the measures of success for non-training subjects in vocational education [24].

In summary, for the understanding of responsibility about the core system, the vocational learning must be delivered to vocational students within a complex web of policy settings, governance arrangements, regulatory environments, and resourcing decisions. This improves vocational learning in vocational education when existing systems support vocational education through advice on the different ways.

\section{CONCLUSION}

The conclusion of this framework is to cultivate vocational teacher responsibility through all levels and components of comprehension related to each other. They mutually support one another. The success of vocational teachers' understanding depends on the extent to which they understand about this framework. However, everything aims to provide understanding responsibility for vocational teachers to be better and to support the economic advancement of their communities and countries.

\section{REFERENCES}

[1] C. H. Jørgensen, "The Role and Meaning of Vocations in The Transition From Education to Work. International Journal of Training Research," Int. J. Train. Res., vol. 11, no. 2, pp. 166-183, 2013.

[2] L. Peng, S. Zhang, and J. Gu, "Evaluating the competency mismatch between master of engineering graduates and industry needs in China," Stud. High. Educ., vol. 41, no. 3, pp. 445-461, 2016.

[3] A. Llorens, J. Berbegal-Mirabent, and $\mathrm{X}$. Llinàs-Audet, "Aligning Professional Skills and Active Learning Methods: An Application for Information and Communications Technology Engineering," Eur. J. Eng. Educ., vol. 42, no. 4, pp. 382-395, 2017.

[4] K. D. Sweetser and T. Kelleher, "Communicated Commitment and Conversational Voice: Abbreviated Measures of Communicative Strategies for Maintaining Organization-Public Relationships," J. Public Relations Res., vol. 8, no. 5-6, pp. 217-231, 2016.

[5] N. A. Mamaril, E. L. Usher, C. R. Li, D. R. Economy, and M. S. Kennedy, "Measuring Undergraduate Students' Engineering Self-Efficacy: A Validation Study," J. Eng. Educ., vol. 105, no. 2, pp. 366-395, Apr. 2016.

[6] F. Turner, S. Brownhill, and E. Wilson, "The Transfer of Content Knowledge in a Cascade Model of Professional Development," Teach. Dev., vol. 21, no. 2, pp. 175-191, 2016.

[7] M. Grosch, "Developing a Competency Standard for TVET Teacher Education in ASEAN Countries," J. Pendidik. Teknol. dan Kejuru., vol. 23, no. 3, pp. 279-287, Apr. 2017.

[8] U. Cheasakul and P. Varma, "The Influence of Passion and Empowerment 
on Organizational Citizenship Behavior of Teachers Mediated by Organizational Commitment," Contaduría y Adm., vol. 61, no. 3, pp. 422-440, 2016.

[9] G. S. Mouzakitis, "The Role of Vocational Education and Training Curricula in Economic Development," Procedia - Soc. Behav. Sci., vol. 2, no. 2, pp. 3914-3920, 2010.

[10] T. Agrawal, "Vocational Education and Training Programs (VET): An Asian Perspective," Asia-Pacific J. Coop. Educ., vol. 14, no. 1, pp. 15-26, 2013.

[11] J. A. Clark, "Does Philosophy of Education Have a Future?," Educ. Philos. Theory, vol. 47, no. 9, pp. 863869, Jul. 2015.

[12] A. Jordan, A. Carlile, and A. Stack Approaches to Learning: A Guide for Teachers. New York: Open University Press, 2008.

[13] J. Dewey, Democracy and Education: An Introduction to the Philosophy of Education. Macmillan, 1916.

[14] L. Woessmann, "The economic case for education," Educ. Econ., vol. 24, no. 1, pp. 3-32, Jan. 2016.

[15] K. Hoeckel, Costs and Benefits in Vocational Education and Training. Paris: OECD, 2008.

[16] J. Hordern, "Higher Apprenticeships in England: Professional and Vocational Formation," Int. J. Train. Res., vol. 13, no. 3, pp. 174-193, 2015.

[17] A. Giddens and S. Griffiths, Sociology. UK: Polity Press, 2006.

[18] G. Shank, L. Brown, and J. Pringle, Understanding Education Research: A Guide to Critical Reading. UK: Taylor \& Francis, 2015.

[19] I. W. Djatmiko, "A Study on the Empowering Teachers' Professional
Development and Quality Assurance to Increase Teachers' Effectiveness in Vocational Secondary Schools," $J$. Pendidik. Teknol. dan Kejuru., vol. 23, no. 2, pp. 144-151, Oct. 2016.

[20] K. Volmari, S. Helakorpi, and R. Frimodt, Competence Framework for VET Professions: Handbook for Practitioners. Finland: Finnish National Board of Education, 2009.

[21] Minister of Education, VET Teachers, and Trainers in Finland. Finland: Ministry of Education, 2006.

[22] R. Frimodt, K. Marsh, and K. Volmari Defining VET Professions Pilot Project. Germany: Finnish National Broad of Education, 2006.

[23] T. Kärner and J. Warwas, "Functional Relevance of Students' Prior Knowledge and Situational Uncertainty During Verbal Interactions in Vocational Classrooms: Evidence From A MixedMethods Study," Empir. Res. Vocat. Educ. Train., vol. 7, no. 1, p. 11, 2015.

[24] Education Council, Preparing Secondary Students for Work: A framework for Vocational Learning and VET Delivered to Secondary Students. Australia: Education Services Australia, 2014.

[25] S. Edward, E. Weedon, and S. Riddell, Attitudes to Vocational Learning: A Literature Review. UK: Scottish Government publications, 2008.

[26] A. T. Henderson and K. L. Mapp, A New Wave of Evidence: The Impact of School, Family, and Community Connections on Student Achievement. Texas: Southwest Educational Development Laboratory, 2002. 